\title{
Boosting nonverbal physician-patient communication in medical education
}

\author{
Impulsionando a comunicação não verbal na educação médica
}

\author{
Emiliana dos Santos Valadares ${ }^{1}$ (D) $\mid$ valadaresemiliana@gmail.com \\ Renata Rodrigues Catani' (1) renata_rcatani@hotmail.com \\ Julianni Bernardelli Lacombe ${ }^{1}$ (D) juliannib@yahoo.com.br \\ Tânia Maria da Silva Mendonça' ${ }^{1}$ taniacore@hotmail.com \\ Carlos Henrique Martins Silva' (1) carloshmed@gmail.com \\ Helena Borges Martins da Silva Paro' (D) helenabmsparo@gmail.com
}

\begin{abstract}
Introduction: Nonverbal communication is an important part of the medical interview. However, nonverbal skills are still underestimated in medical education and instruments for their teaching and assessing in medical schools are scarce.

Objective: We aimed to translate and culturally adapt the Relational Communication Scale for Observational measurement of doctor-patient interactions (RCS-O) to Brazilian Portuguese.

Methods: We translated the RCS-O in seven stages: initial translation, reconciliation, back translation, review by the author, independent review, consensus version through the Delphi technique, review by a language coordinator, and pre-test. We used video recordings of four medical consultations performed by medical students and residents to pre-test the instrument. During this phase, three independent observers assessed the medical students and residents' performance in real health care scenarios through the use of the recordings.

Results: Most of the difficulties regarding the translation and cultural adaptation were related to the polysemic meaning of some items. Words and expressions such as "stimulating", "warmth", "desire", "relaxed", "conversation to a deeper level", "deeper relationship", "casual", and "intensely" required adaptation in order to remove the potential sexual connotation that could arise from overintimacy in the physician-patient relationship.

Conclusion: The Brazilian version of the RCS-O is a culturally, conceptually, semantically and operationally valid instrument. It may represent an important advance for the strengthening of learning and assessing nonverbal communication in medical education. We hope this study may encourage health educators to invest in the teaching and assessment of nonverbal communication skills in other countries.
\end{abstract}

Keywords: Cross-Cultural Comparison; Medical Education; Educational Measurement; Nonverbal Communication; Physician-Patient Relations.

\section{RESUMO}

Introdução: A comunicação não verbal corresponde a importante parte da entrevista médica. No entanto, as habilidades não verbais ainda são subestimadas na educação, e os instrumentos para ensino e avaliação nas escolas de saúde são escassos.

Objetivo: Nosso objetivo foi traduzir e adaptar culturalmente a Relational Communication Scale for Observational measurement of doctor-patient interactions (RCS-O) para o português do Brasil.

Método: Traduzimos a RCS-O em sete etapas: tradução inicial, reconciliação, retrotradução, revisão pelo autor, revisão independente, consenso pela técnica Delphi, revisão por um coordenador de linguagem e pré-teste. Utilizamos gravações de quatro consultas médicas realizadas por estudantes de Medicina e residentes para pré-testar o instrumento. Durante essa fase, três observadores independentes avaliaram o desempenho de estudantes de Medicina e residentes em cenários reais de assistência médica por meio do uso das gravações.

Resultados: A maioria das dificuldades de tradução e adaptação cultural foi relacionada ao significado polissêmico de alguns itens. Palavras e expressões como "stimulating", "warmth", "desire", "relaxed", "conversation to a deeper level", "deeper relationship", "casual", and "intensely" precisaram ser adaptadas para remover a conotação sexual que poderia surgir da intimidade presente na relação médico-paciente.

Conclusão: A versão brasileira da RCS-O é cultural, conceitual, semântica e operacionalmente válida. Representa um avanço importante para o ensino e a avaliação da comunicação não verbal na educação médica. Esperamos que este estudo possa incentivar educadores de saúde a investir no ensino e na avaliação dessas habilidades nas escolas médicas.

Palavras-chaves: Comparação Transcultural; Educação Médica; Avaliação Educacional; Comunicação não Verbal; Relações Médico-Paciente.

${ }^{1}$ Universidade Federal de Uberlândia, Uberlândia, Minas Gerais, Brazil.

Chief Editor: Daniela Chiesa

Associate Editor: Rosiane Viana Zuza Diniz

Received on 08/18/20; Accepted on 03/14/21.

Evaluated by double blind review process. 


\section{INTRODUCTION}

Nonverbal communication is an important part of medical interviewing ${ }^{1}$, corresponding to nearly $60 \%$ of doctor-patient interaction $\mathrm{s}^{2-5}$. Nonverbal communication has been widely researched outside the medical field ${ }^{6,7}$. In the medical literature, studies have suggested that nonverbal communication plays an important role in the physician-patient relationship ${ }^{8}$, being associated with patient satisfaction ${ }^{9-11}$, emotional distress ${ }^{12}$, symptom resolution ${ }^{13}$, and malpractice claims ${ }^{14}$.

Despite such evidence, nonverbal skills are still underestimated in medical education. Few interventions designed to improve medical students' nonverbal behavior are reported in the medical education research field. Uncertainties on whether nonverbal behavior may be developed through educational interventions might explain this paucity of evidence ${ }^{10,15-17}$. Some authors believe nonverbal behavior is innate ${ }^{18}$, while others admit that this behavior is culture-specific and can be learned ${ }^{19}$. We assume that nonverbal communication skills are determined by a fusion of these extremes ${ }^{5}$.

Considering nonverbal communication - posture, gesture, eye contact, tone of voice, and proximity, that is, aspects of an actor's demeanor that frame the message content - as a trainable skill $8,20,21$, the existence of appropriate instruments for teaching and assessing the nonverbal behavior of physicians and medical students is mandatory. The Relational Communication Scale for Observational measurement of doctor-patient interactions (RCS-O) is an instrument specifically developed to measure the relational communication aspects of the doctor-patient interaction. It is practical to administer and can be used in formative assessments of medical students and physicians ${ }^{22}$. Since the RCS-O has been originally developed in the United States, its use in other countries must be preceded by the adequate processes of translation, cultural and linguistic adaptation ${ }^{23}$. Such processes are particularly important as nonverbal skills vary between different situations and cultures ${ }^{24-26}$.

The RCS-O is used for the direct observation of the doctor-patient relationship, with good psychometric properties for the majority of its items and domains. To the best of our knowledge, the RCS-O is the only validated instrument that was specifically developed to measure the relational aspects of non-verbal behavior during the interaction between doctor and patient ${ }^{22}$.

This research reinforces the importance of nonverbal communication as a powerful medical skill and aims to translate and culturally adapt the RCS-O to Brazilian Portuguese. The scale will be used to assist medical educators in designing and evaluating educational interventions tailored to improve students' nonverbal communication with patients.

\section{METHODS}

This is a cross-cultural adaptation study, which was approved by the local research ethics committee, carried out after permission by Judee Burgoon, the instrument's author.

\section{Instrument}

The RCS-O is a validated version for third-party observers of doctor-patient interactions of the Burgoon and Hales' relational communication scale $(\mathrm{RCS})^{22,27-30}$. The scale was specifically developed to produce a global measure of the relational component of doctor-patient interactions, handled primarily through nonverbal channels ${ }^{22}$. It comprises 34 items arranged in six dimensions.

The six dimensions are divided as follows: (1) intimacy IA immediacy/affection - the degree to which closeness or distance is expressed, (2) intimacy (SD - similarity/depth) the degree to which the interactants feel alike or different, (3) intimacy (RT - receptivity/trust) - the degree to which interest and concern or lack of interest and disregard are expressed, (4) composure (C) - the degree to which one is calm or anxious, (5) formality $(F)$ - the degree to which the interaction is formal or relaxed and (6) dominance (D) - the degree to which power is shared or unequal ${ }^{22}$.

The instrument can be used in formative assessment of physicians and medical students ${ }^{22}$. Answers are rated on a seven-point Likert scale ranging from "strongly disagree" to "strongly agree". Scores range from 34 to 228 , with higher scores indicating the ability to put the patient at ease and develop an equal partnership with the patient. Doctors with higher scores demonstrate openness by revealing a professional demeanor that is friendly, approachable, and relaxed. The RCS-O is a psychometrically sound instrument used to measure relational communication skills not only in patient-centered, but also in doctor-centered approaches $22,27,28,30$.

\section{Translation and cultural adaptation}

The translation and cultural adaptation of the instrument were performed according to international guidelines $^{31,32}$ (Figure 1). In the first stage - forward translation - two bilingual translators native of Brazilian Portuguese produced two independent translations of the instrument from English into Brazilian Portuguese. In the second stage, a bilingual healthcare professional native of Brazilian Portuguese performed the reconciliation of the previous translations. In the third stage (back translation), an American translator fluent in Portuguese translated the reconciled version back into the original language. In the fourth stage, the author of the instrument made comments on the back-translated version. 
Figure 1. Translation and cultural adaptation process.

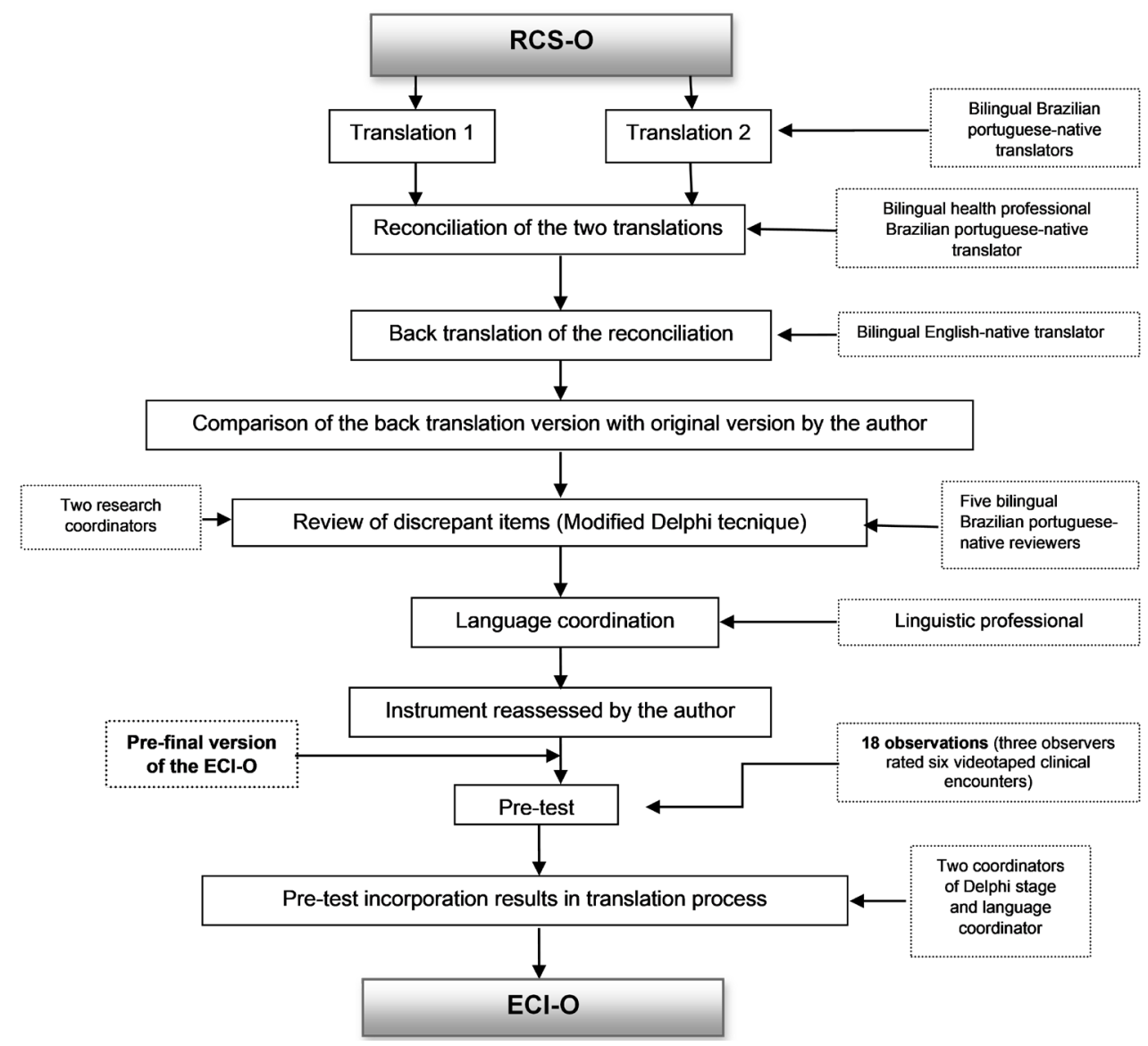

ECI-O: Escala de Comunicação Interpessoal para avaliação Observacional das interações médico-paciente (Interpersonal Communication Scale for Observational Assessment of doctor-patient interactions).

(Final Brazilian Portuguese version of the RCS-O).

In the fifth stage, items, behavior categories, expressions, sentences or words identified as lacking semantic, idiomatic, experimental or conceptual equivalences at any stage of the translation process were sent to be reviewed. Five bilingual reviewers native of Brazilian Portuguese (two professional translators and three physicians experienced in the process of translation of outcome measures) assessed all previous stages to choose the best translation option for the instrument. The modified Delphi technique ${ }^{33,34}$, was used to reach a consensus among reviewers in interactive electronic rounds organized by two research coordinators in semi-structured questionnaires on the Delphi Decision Aid website ${ }^{35}$.

After each round, independent reviewers received feedback on the statistical analysis of responses. They also received suggestions made by other reviewers in each round. The questionnaires answered by the independent reviewers comprised the entire translation process and were available to the reviewers during the whole process, which totaled three rounds. The process was completed after meeting at least $80 \%$ of consensus among the participants ${ }^{36,37}$. The instrument was then sent for evaluation by a language coordinator and for a new analysis by the author (stage six), to produce the pre-final version.

\section{Pre-test}

Three interns, three medical residents, and six patients provided informed consent for the recording of their clinical outpatient encounters held at the university hospital of our institution.

Three observers from the faculty of our institution used the pre-final Brazilian version of RCS-O (stage seven) to assess four videotaped clinical encounters between real patients and medical students and residents. This video approach is useful and reliable for analyzing physician-patient nonverbal communication interactions in medical settings $\mathrm{s}^{38}$.

The observers obtained instructions during a two-hour meeting, when observers and research coordinators discussed about the scale nature, conception, and use. A relational communication analysis was also part of the topics covered during the meeting. Each observer received a flash drive with the pre-final version of the scale, instructions for rating the instrument, a manual, and a video lesson containing information 
about the scale and about nonverbal communication skills.

The observers underwent a retrospective and cognitive interview in order to check understanding and applicability of the items and domains ${ }^{37}$. Research and language coordinators analyzed suggestions given by the observers and incorporated them, when relevant, into the final Brazilian version of the RCS-O (supplementary material). The final items were named after the domain and number in the original scale (e.g., Item 3 - domain Intimacy I - immediacy/affection = IA3). The items were randomly arranged before instrument administration.

The number of videotaped clinical encounters (4) and observers (3) (totaling twelve observations) was enough to conclude the cultural adaptation of the instrument, although it was insufficient to perform any statistical analysis for validation purposes. Sample sizes of five to 12 participants in the pre-test phase have been used in several cultural adaptation studies ${ }^{39-43}$.

\section{RESULTS}

The RCS-O title and items "The physician did not want a deeper relationship with the patient" (IA2), "The physician communicated coldness rather than warmth" (IA5), and "The physician seemed to desire further communication with the patient" (SP13) were reviewed after the back translation and the author's comments. These items were then analyzed through the modified Delphi technique rounds. The item IA5 reached consensus (100\% agreement) only after four rounds (Table 1).

At the end of the translation process, the language coordinator adjusted nine (26.4\%) items. The adjustments were grouped into five categories: Conventionality pragmatic level,

Table 1. Process to solve discrepant item translations using the modified Delphi technique.

\begin{tabular}{|c|c|c|c|c|}
\hline Original Item & & Translations & $\begin{array}{l}\text { Number } \\
\text { of rounds } \\
\text { to reach } \\
\text { consensus }\end{array}$ & $\begin{array}{l}\text { Percentage of } \\
\text { consensus }\end{array}$ \\
\hline \multirow{5}{*}{$\begin{array}{c}\text { Title } \\
\text { Relational communication scale } \\
\text { for observational measurement } \\
\text { of doctor-patient interactions } \\
\text { (RCS-O) }\end{array}$} & $T 1$ & $\begin{array}{l}\text { Escala de comunicação relacional para a medição de observação } \\
\text { das interações médico-paciente (RCS-O) }\end{array}$ & \multirow{5}{*}{2} & \multirow{5}{*}{$80 \%$} \\
\hline & $T 2$ & $\begin{array}{l}\text { Escala de comunicação relacional para a medição de observação } \\
\text { das interações médico-paciente (RCS-O) }\end{array}$ & & \\
\hline & REC & $\begin{array}{l}\text { Escala de comunicação relacional para medida observacional das } \\
\text { interações médico-paciente (ECR-O) }\end{array}$ & & \\
\hline & $R T$ & $\begin{array}{l}\text { Communicational relations scale for measuring observations of } \\
\text { the interaction between physician and patient (CRS-O) }\end{array}$ & & \\
\hline & Pre-final & $\begin{array}{l}\text { Escala de comunicação interpessoal para medida observacional } \\
\text { das interações médico-paciente (ECI-O) }\end{array}$ & & \\
\hline \multirow{5}{*}{$\begin{array}{l}\text { IA2 item } \\
\text { The physician did not want a } \\
\text { deeper relationship with the } \\
\text { patient }{ }^{b}\end{array}$} & $T 1$ & O médico não quis uma relação mais profunda com o paciente ${ }^{b}$ & \multirow{5}{*}{2} & \multirow{5}{*}{$80 \%$} \\
\hline & $T 2$ & O médico não quis uma relação mais aprofundada com o paciente ${ }^{b}$ & & \\
\hline & REC & O médico não quis uma relação mais aprofundada com o paciente ${ }^{b}$ & & \\
\hline & $R T$ & $\begin{array}{l}\text { The physician did not want a more intimate relation with the } \\
\text { patient }^{\text {b }}\end{array}$ & & \\
\hline & Pre-final & $\begin{array}{l}\text { O(a) médico(a) não quis uma relação mais próxima com o(a) } \\
\text { paciente }^{b}\end{array}$ & & \\
\hline \multirow{5}{*}{$\begin{array}{l}\text { IA5 item } \\
\text { The physician communicated } \\
\text { coldness rather than warmth }{ }^{\mathrm{b}}\end{array}$} & $T 1$ & O médico comunicou-se de forma fria ao invés de cordial ${ }^{b}$ & \multirow{5}{*}{4} & \multirow{5}{*}{$100 \%$} \\
\hline & $T 2$ & O médico comunicou-se com frieza ao invés de cordialidade ${ }^{b}$ & & \\
\hline & REC & O médico comunicou-se friamente ao invés de calorosamente ${ }^{b}$ & & \\
\hline & $R T$ & $\begin{array}{l}\text { The physician communicated in a cold way, rather than } \\
\text { warmly }{ }^{b}\end{array}$ & & \\
\hline & Pre-final & $O(A)$ médico $(a)$ transmitiu frieza ao invés de cordialidade ${ }^{b}$ & & \\
\hline \multirow{5}{*}{$\begin{array}{l}\text { SP13 item } \\
\text { The physician seemed to desire } \\
\text { further communication with the } \\
\text { patient }\end{array}$} & $T 1$ & O médico pareceu desejar mais comunicação com o paciente & \multirow{5}{*}{2} & \multirow{5}{*}{$80 \%$} \\
\hline & $T 2$ & $\begin{array}{l}\text { O médico pareceu desejar uma maior comunicação com o } \\
\text { paciente }\end{array}$ & & \\
\hline & REC & O médico pareceu desejar manter a comunicação com o paciente & & \\
\hline & $R T$ & $\begin{array}{l}\text { The physician seemed to want to maintain communication with } \\
\text { the patient }\end{array}$ & & \\
\hline & Pre-final & $\begin{array}{l}\mathrm{O}(\mathrm{A}) \text { médico(a) pareceu desejar continuar a comunicação com } \\
\text { o paciente }\end{array}$ & & \\
\hline
\end{tabular}

T1 - Forward Translation 1;T2 - Forward Translation 2; REC - Reconciliation; RT - Back translation; ${ }^{\mathrm{b}}$ - items must be reverse-coded before analyzing the data. 
conventionality syntactic level, ambiguity/polysemy, literal translation and comprehension (Table 2). Items that required modification generally belonged to the intimacy domains I and II. Items IA2, IA5, and SP13 required more than one change. In the item IA2, both changes were in the combinality category. Five items were adjusted due to ambiguity/polysemy (Table 2).

All pre-test observers considered the instrument comprehensible and easy to apply. One of them, aiming to ensure familiarity in identifying clues related to certain nonverbal behaviors, strengthened the importance of previous training with the scale. Another observer suggested that the instrument should be used for teaching and assessing not only physicians and medical students, but also other health professionals.

After the pre-test, research and language coordinators replaced the words "casual" (item F27) and "relaxado(a)" (item
C23) by the words "descontraída" and "tranquilo(a)", respectively, as suggested by observers (Table 3 ).

\section{DISCUSSION}

Although nonverbal communication is present in every social interaction, it is still underestimated in scientific studies ${ }^{8}$. To our knowledge, this is the first Brazilian translation and cultural adaptation study of an instrument for teaching and assessing nonverbal medical students' and physicians' skills in relational communication in the clinical encounter.

During the translation process, words were changed in order to remove the sexual connotation that could arise from overintimacy in the physician-patient relationship. The words "stimulating", "warmth", "desire", "relaxed", "conversation to a deeper level", "deeper relationship", "casual", and "intensely" were changed in the consensus stage by independent reviewers, the

Table 2. Main adjustments due to inconsistencies in the translation process of the Brazilian RCS-O items.

\begin{tabular}{|c|c|c|c|}
\hline \multirow{2}{*}{ Adjustment category } & \multirow{2}{*}{ Items } & \multicolumn{2}{|c|}{ Examples } \\
\hline & & Reconciliation & Final version \\
\hline & & $\begin{array}{l}\text { Title - Escala de Comunicação } \\
\text { Relacional para medida } \\
\text { Observacional das interações médico- } \\
\text { paciente (ECR-O) }\end{array}$ & $\begin{array}{l}\text { Title - Escala de Comunicação } \\
\text { Interpessoal para avaliação } \\
\text { Observacional das interações } \\
\text { médico-paciente (ECl-O) }\end{array}$ \\
\hline $\begin{array}{l}{ }^{*} \text { Conventionality } \\
\text { Pragmatic level }\end{array}$ & Title, C21, C23 & $\begin{array}{l}\text { C21 - O médico sentiu-se muito } \\
\text { tenso ao conversar com o paciente }{ }^{b} \\
\text { C23 - O médico sentiu-se muito } \\
\text { relaxado ao conversar com o paciente }\end{array}$ & $\begin{array}{l}\text { C21 - O }(A) \text { médico }(a) \text { pareceu } \\
\text { muito tenso(a) ao conversar com } \\
O(a) \text { paciente b } \\
\text { C23-O(A) médico(a) pareceu } \\
\text { muito tranquilo }(a) \text { ao conversar } \\
\text { com o(a) paciente }\end{array}$ \\
\hline $\begin{array}{l}{ }^{*} \text { Conventionality } \\
\text { Syntactic level (Combinality) }\end{array}$ & $I A 2, I A 5, I A 6, D 34$ & $\begin{array}{l}\text { IA2 - O médico não quis uma relação } \\
\text { mais aprofundada com o paciente }{ }^{b} \\
\text { D34 - O médico dominou } a \\
\text { conversação }\end{array}$ & $\begin{array}{l}\text { IA2 - O (A) médico (a) não quis } \\
\text { estabelecer uma relação mais } \\
\text { próxima com o(a) paciente }{ }^{b} \\
\text { D34 - } O(A) \text { médico }(a) \text { teve controle } \\
\text { sob a conversa }\end{array}$ \\
\hline *Ambiguity/polysemy & $I A 2, I A 4, I A 5, S P 13, C 23$ & $\begin{array}{l}\text { IA4 - O médico achou a conversa } \\
\text { estimulante } \\
\text { IA5 - O médico comunicou-se } \\
\text { friamente ao invés de calorosamente } \\
\text { SP13 - O médico pareceu desejar } \\
\text { manter a comunicação com o paciente } \\
\text { C23 - O médico sentiu-se muito } \\
\text { relaxado ao conversar com o paciente }\end{array}$ & $\begin{array}{l}\text { IA4 - O }(A) \text { médico }(a) \text { achou a } \\
\text { conversa empolgante } \\
\text { IA5 - O }(A) \text { médico }(a) \text { transmitiu } \\
\text { frieza ao invés de cordialidade } b \\
\text { SP13 - } O(A) \text { médico }(a) \text { pareceu } \\
\text { querer continuar a conversa com } \\
\text { o(a) paciente } \\
\text { C23 - O médico pareceu muito } \\
\text { tranquilo }(\boldsymbol{a}) \text { ao conversar com o } \\
\text { paciente }\end{array}$ \\
\hline${ }^{*}$ Literal translation & SP11 & $\begin{array}{l}\text { SP11 - O médico tentou direcionar } \\
\text { a conversa a um nível mais } \\
\text { aprofundado }\end{array}$ & $\begin{array}{l}\text { SP11 - } O(A) \text { médico }(a) \text { tentou } \\
\text { direcionar a conversa para } \\
\text { aprofundar no assunto }\end{array}$ \\
\hline${ }^{*}$ Comprehension & $S P 13, F 27, D 31$ & $\begin{array}{l}\text { SP13 - O médico pareceu desejar } \\
\text { manter a comunicação com o } \\
\text { paciente } \\
\text { F27 - O médico quis que a discussão } \\
\text { fosse casual } \\
\text { D31 - O médico tentou controlar a } \\
\text { interação }\end{array}$ & $\begin{array}{l}\text { SP13 - O(A) médico(a) pareceu } \\
\text { querer continuar a conversa com } \\
\text { o(a) paciente } \\
\text { F27-O(A) médico quis que a } \\
\text { discussão fosse descontraída } \\
\text { D31 - O(A) médico(a) tentou controlar } \\
\text { a interação com o paciente }\end{array}$ \\
\hline
\end{tabular}

Domain encoding [IA - immediacy/affection (I), SP - similarity/depth (II), C - composure (IV) e D - dominance (VI)], followed by item encoding (1 to 34); words and expressions in bold - adjustments. 
Table 3. Pre-final, pre-test suggestions and final version of Brazilian RCS-O.

\begin{tabular}{|c|c|c|}
\hline Pre-final item & Pre-test suggestion & Final item \\
\hline $\begin{array}{l}\text { IA1 - } \mathrm{O}(\mathrm{A}) \text { médico(a) estava } \\
\text { intensamente envolvido(a) na } \\
\text { conversa com o(a) paciente }\end{array}$ & $\begin{array}{l}\text { IA1 - } O(A) \text { médico(a) estava bastante } \\
\text { envolvido(a) na conversa com o(a) paciente }\end{array}$ & $\begin{array}{l}\text { IA1 - } \mathrm{O}(\mathrm{A}) \text { médico(a) estava } \\
\text { intensamente envolvido(a) na conversa } \\
\text { com o(a) paciente }\end{array}$ \\
\hline $\begin{array}{l}\text { SP13 - } \mathrm{O}(\mathrm{A}) \text { médico(a) pareceu querer } \\
\text { continuar a comunicação com o(a) } \\
\text { paciente }\end{array}$ & $\begin{array}{l}\text { SP13 - } O(A) \text { médico(a) pareceu querer } \\
\text { continuar a conversa com o(a) paciente }\end{array}$ & $\begin{array}{l}\mathrm{SP} 13-\mathrm{O}(\mathrm{A}) \text { médico(a) pareceu querer } \\
\text { continuar a comunicação com o(a) } \\
\text { paciente }\end{array}$ \\
\hline $\begin{array}{l}\mathrm{C} 23-\mathrm{O}(\mathrm{A}) \text { médico }(\mathrm{a}) \text { pareceu muito } \\
\text { relaxado(a) ao conversar com o(a) } \\
\text { paciente }\end{array}$ & $\begin{array}{l}\mathrm{C} 23-\mathrm{O}(\mathrm{A}) \text { médico(a) pareceu muito } \\
\text { tranquilo(a) ao conversar com o(a) paciente }\end{array}$ & $\begin{array}{l}\mathrm{C} 23-\mathrm{O}(\mathrm{A}) \text { médico(a) pareceu muito } \\
\text { tranquilo(a) ao conversar com o(a) } \\
\text { paciente }\end{array}$ \\
\hline $\begin{array}{l}\mathrm{F} 27-\mathrm{O}(\mathrm{A}) \text { médico(a) quis que a } \\
\text { discussão fosse casual } \mathrm{b}\end{array}$ & $\begin{array}{l}F 27 \text { - } O(A) \text { médico(a) quis que a discussão } \\
\text { fosse descontraída } b\end{array}$ & $\begin{array}{l}F 27-O(A) \text { médico(a) quis que a } \\
\text { discussão fosse descontraída } b\end{array}$ \\
\hline
\end{tabular}

Domain encoding [IA - immediacy/affection (I), SP - similarity/depth (II), C - composure (IV) e F - formality (V)], followed by item encoding (1 to 34); words and expressions in bold - proposed adjustments.

language coordinator, or during the pre-test. Those changes were particularly important considering this instrument will be used to teach/assess nonverbal communication skills.

The word "desire" (item SP13) may illustrate problems related to polysemy in the teaching/assessment of nonverbal communication skills. This verb holds an ambiguous characteristic, both in English and in Brazilian Portuguese: it means (1) to want something, to wish for something, and (2) to be sexually attracted to somebody ${ }^{44}$. This explains our choice to use the verb "to want" instead of using "to desire" in the final Brazilian version of the RCS-O.

Likewise, on account of polysemic meanings in Brazilian Portuguese, we decided to change the words "relaxed" (item C23) and "casual" (item F27). In English, "relaxed" is an adjective that represents concepts of being calm, not anxious38 and it does not have the pejorative connotation of carelessness or displeasure on the part of the doctor towards the patient, as it may be case in Brazilian Portuguese ${ }^{45}$. "Casual", on the contrary, is also a polysemic word in English, and we chose the adjective "descontraída" to convey the non-formal connotation intended by the scale. "Relaxed" and "casual" could also sound as lack of professionalism in the physician-patient relationship.

Those interpretations and assessments in the translation process called our attention. The examples above bring to discussion the type of intimacy established between physician and patient. Intimacy (physical intimacy/contact and emotional intimacy/feelings) is part of the physicianpatient relationship and it is necessary in the therapeutic process. However, it makes patients vulnerable to damages when the limits of this intimacy are crossed ${ }^{46}$.

Establishing the limits of appropriate and inappropriate intimacy indicates efficiency, reliability, and, as a consequence, good health practice. The ideal limit can be developed and strengthened by the teaching of basic skills, including behavioral ones. The physician's attention and sensibility to their own nonverbal behavior ${ }^{46}$ is crucial to good communication and high-quality clinical encounters ${ }^{47}$.

Although some studies have claimed that nonverbal behavior is mandatory for good medical care, there still is a limited comprehension of the meaning of nonverbal clues, especially concerning the physician-patient interaction ${ }^{46}$. Assessing this behavior requires caution (Mast, 2007), since many factors may change the "reading" of the nonverbal behavior. Nonverbal behavior expressing intimacy and interest can be understood either as affection or as threat when expressed by strangers ${ }^{8}$. Similarly, persistent and direct eye contact can be understood as an invasive or a thoughtful behavior ${ }^{46}$.

Interpreting this communication may vary according to different factors. Cultural ${ }^{47}$, ecological and historical factors experienced by a particular society (such as wars and agricultural systems ${ }^{48}$, personality and connection/intimacy between people ${ }^{8}$ may play an important role in nonverbal communication. The hierarchical relation in the physician-patient interaction ${ }^{49}$ is also an important influencing issue in clinical communication.

Despite those influencing factors and the possibility of different interpretations of nonverbal communication, we should not underestimate the importance of teaching and evaluating this skill. The main medical education guidelines ${ }^{50-52}$ state that physicians should constantly watch nonverbal communication in professional health care.

Physicians that are able to cross intercultural borders inherent to any clinical encounter by having adequate behavioral skills are also able to simplify patient-centered health care $^{47}$ and establish a more effective vertical communication ${ }^{49}$.

In this context, research on medical education requires teaching and assessment instruments concerning nonverbal communication skills. The use of rigorous translation and adaptation techniques with the participation of a panel of qualified experts and language coordinators in our study resulted in a sound instrument to be used in the Brazilian medical education. 
Our study has some limitations. We used video recordings for pretesting the instrument. This approach may have influenced our results. Although video recordings have been used in the original scale validation studies ${ }^{22}$, this approach may have posed difficulties in assessing students' and physicians' nonverbal behavior. Nevertheless, the video approach is used to assess reliability of other nonverbal communication instruments in medical settings38. Also, our sample size did not allow the use of factor analysis of the RCS-O for validation analysis. Therefore, we encourage future validation studies to test the structural validity of the instrument.

\section{CONCLUSION}

The process of translation and cultural adaptation of the RCS-Oto Brazilian Portuguese resulted in a suitable instrument to be introduced as a tool for teaching and assessing interpersonal communication skills in medical education. Validation studies are needed to elucidate the psychometric parameters of the items and domains of the Brazilian version, especially those adjusted for cultural issues related to intimacy in the doctorpatient relationship. We hope this study may encourage health educators to invest in the teaching and assessment of nonverbal communication skills in other countries.

\section{AUTHORS' CONTRIBUTION}

Emiliana S. Valadares: designed the study and contributed to the design and implementation of the research, the analysis of the results and the writing of the manuscript. Renata Rodrigues Catani: contributed to the design and implementation of the research, the analysis of the results and the writing of the manuscript. Julianni Bernardelli Lacombe: contributed to the implementation of the research and the writing of the manuscript. Tânia M. S. Mendonça: contributed to the analysis of the results and the writing of the manuscript. Carlos Henrique Martins Silva: contributed to the implementation of the research, the analysis of the results and the writing of the manuscript. Helena Borges Martins da Silva Paro: designed the study and contributed to the design and implementation of the research, the analysis of the results and the writing of the manuscript.

\section{CONFLICTS OF INTEREST}

The authors declare that there are no conflicts of interests.

\section{SOURCES OF FUNDING}

None to be declared.

\section{REFERENCES}

1. Mast MS. On the importance of nonverbal communication in the physician-patient interaction. Patient Educ Couns. 2007;67(3):315-8.
2. Mehrabian A. Inference of attitudes from the posture, orientation, and distance of a communicator. J Consult Clin Psychol. 1968;32(3):296-308.

3. Applbaum RL. Intra-rater reliability: A function of scale complexity and rater training? Cent States Speech J. 1974;25(4):277-81.

4. Rector M, Aluizio T. Comunicação não-verbal: a gestualidade brasileira. 2nd ed. Petrópolis: Vozes; 1986. p. 184.

5. Burgoon JK, Buller DB, Woodall WG. Nonverbal communication: the unspoken dialogue. 2nd ed. New York: McGraw-Hill; 1996. p. 535.

6. Burgoon JK, Guerrero LK, Floyd K. Nonverbal Communication. Routledge; 2016. p. 528.

7. Matsumoto $\mathrm{D}$, Hwang $\mathrm{HC}$. The cultural bases of nonverbal communication In: Matsumoto D, Hwang HC, Frank MG, editors. APA handbook of nonverbal communication. Washington, DC, US: American Psychological Association; 2016. p. 77-101.

8. Mast MS. On the importance of nonverbal communication in the physician-patient interaction. Patient Educ Couns. 2007;67(3):315-8.

9. Larsen $\mathrm{K}$, Smith $\mathrm{C}$. Assessment of nonverbal communication in the patient-physician interview. J Fam Pract. 1981;12(3):481-8.

10. Hall JA, Harrigan JA, Rosenthal R. Nonverbal behavior in clinician—patient interaction. Appl Prev Psychol. 1995;4(1):21-37.

11. Griffith $\mathrm{CH}$, Wilson JF, Langer $\mathrm{S}$, Haist SA. House staff nonverbal communication skills and standardized patient satisfaction. J Gen Intern Med. 2003;18(3):170-4.

12. Roter DL, Hall JA, Kern DE, Barker LR, Cole KA, Roca RP. Improving physicians' interviewing skills and reducing patients' emotional distress. A randomized clinical trial. Arch Intern Med. 1995;155(17):1877-84.

13. Ong LML, de Haes JCJM, Hoos AM, Lammes FB. Doctor-patient communication: A review of the literature. Soc Sci Med. 1995;40(7):903-18

14. Ambady N, Koo J, Rosenthal R, Winograd CH. Physical therapists'nonverbal communication predicts geriatric patients' health outcomes. Psychol Aging. 2002;17(3):443-52.

15. Boon $H$, Stewart M. Patient-physician communication assessment instruments: 1986 to 1996 in review. Patient Educ Couns. 1998;35(3):161-76.

16. Roter D, Hall JA. Doctors Talking with Patients/patients Talking with Doctors: Improving Communication in Medical Visits. Greenwood Publishing Group; 2006. p. 256.

17. Del Piccolo L, Finset A. Assessment of nonverbal communication in clinical encounters: many methodological approaches, but no gold standard. Patient Educ Couns. 2012;86(3):279-80.

18. Izard CE. Innate and universal facial expressions: evidence from developmental and cross-cultural research. Psychol Bull. 1994;115(2):288-99.

19. Russell JA. Facial expressions of emotion: what lies beyond minimal universality? Psychol Bull. 1995;118(3):379-91.

20. Knapp ML, Hall JA. Comunicação nào-verbal na interação humana. São Paulo (SP): JSN; 1999.

21. Molinuevo B, Escorihuela RM, Fernández-Teruel A, Tobeña A, Torrubia R. How we train undergraduate medical students in decoding patients' nonverbal clues. Med Teach. 2011;33(10):804-7.

22. GallagherTJ, Hartung PJ, Gerzina H, Gregory SW, Merolla D. Further analysis of a doctor-patient nonverbal communication instrument. Patient Educ Couns. 2005;57(3):262-71.

23. Reichenheim ME, Moraes $\mathrm{CL}$. [Operationalizing the cross-cultural adaptation of epidemiological measurement instruments]. Rev Saude Publica. 2007;41(4):665-73.

24. Schouten BC, Meeuwesen L. Cultural differences in medical communication a review of the literature. Patient Educ Couns. 2006;64(1-3):21-34.

25. Mistry H, Bhugra D, Chaleby K, Khan F, Sauer J. Veiled communication: is uncovering necessary for psychiatric assessment? Transcult Psychiatry 2009;46(4):642-50.

26. Williams S, Harricharan $M$, Sa B. Nonverbal Communication in a Caribbean Medical School: "Touch Is a Touchy Issue." Teach Learn Med. 2013;25(1):39-46 
27. Burgoon JK, Hale JL. The fundamental topoi of relational communication. Commun Monogr. 1984;51(3):193-214.

28. Burgoon JK, Hale JL. Validation and measurement of the fundamental themes of relational communication. Commun Monogr. 1987;54(1):19-41.

29. Rubin RB, Palmgreen P, Sypher HE. Communication research measures: a sourcebook. New York: Guilford Press; 1994.

30. Gallagher TJ, Hartung PJ, Gregory SW. Assessment of a measure of relational communication for doctor-patient interactions. Patient Educ Couns. 2001;45(3):211-8.

31. Beaton DE, Bombardier C, Guillemin F, Ferraz MB. Guidelines for the process of cross-cultural adaptation of self-report measures. Spine. 2000;25(24):3186-91.

32. Eremenco SL, Cella D, Arnold BJ. A comprehensive method for the translation and cross-cultural validation of health status questionnaires. Eval Health Prof. 2005;28(2):212-32.

33. Armstrong J. Delphi Decision Aid. The Wharton School, University of Pennsylvania, Philadelphia; [access in 15 apr 2017]. Available from: http:// armstrong.wharton.upenn.edu/delphi2/admin.php.

34. Pereira CMAS, Amaral CFS, Ribeiro MMF, Paro HBMS, Pinto RMC, Reis LET, et al. Cross-cultural validation of the Patient-Practitioner Orientation Scale (PPOS). Patient Educ Couns. 2013;91(1):37-43.

35. Armstrong J. Delphi Decision Aid. Whart Sch Univ Pa Phila PA. 2003; [access in 15 apr 2017]. Available from: http://armstrong.wharton.upenn. edu/delphi2/.

36. Hsu C, Sandford B. The Delphi technique: making sense of consensus. 2007;12(10):1-8.

37. Ruperto N, Ravelli A, Pistorio A, Malattia C, Cavuto S, Gado-West L, et al. Cross-cultural adaptation and psychometric evaluation of the Childhood Health Assessment Questionnaire (CHAQ) and the Child Health Questionnaire (CHQ) in 32 countries. Review of the general methodology. Clin Exp Rheumatol. 2001;19(4 Suppl 23):S1-9.

38. Hart $Y$, Czerniak E, Karnieli-Miller O, Mayo AE, Ziv A, Biegon A, et al. Automated Video Analysis of Non-verbal Communication in a Medical Setting. Front Psychol. 2016;7:1130.

39. Streiner DL, Norman GR. Health Measurement Scales. A practical guide to their development and use (3rd ed.). Oxford: Oxford University Press; 2003.
40. Beatty PC, Willis GB. Research synthesis: The practice of cognitive interviewing. Public Opinion Quarterly. 2007;71:287-311.

41. Wild D, Grove A, Martin M, Eremenco S, McElroy S, Verjee-Lorenz A, et al. Principles of good pratice for the translation and cultural adaptation process for patient-reported outcomes (PRO) measures: Report of the ISPOR task force for translation and cultural adaptation. Value Health. 2005;8:94-104.

42. Patrick DL, Burke LB, Gwaltney CJ, Kline LN, Martin L, Molsen E, et al. Content validity-Establishing and reporting the evidence in newly developed patient-reported outcomes (PRO) instruments for medical product evaluation: IS-POR PRO good research practices task force report: Part 2-Assessing respondent understanding. Value Health. 2011;14:978-88.

43. Sprangers MA, Cull A, Groenvold M, Bjordal K, Blazeby J, Aaronson NK. The European Organization for Research and Treatment of Cancer approach to developing questionnaire modules: An update and overview. Quality of Life Research. 1998;7:291-300.

44. Hornby AS, Deuter M, Turnbull J, Bradbury J, Oxford University Press, editors. Oxford advanced learner's dictionary of current English. Ninth edition. Oxford; New York: Oxford University Press; 2015. p. 1820.

45. Aulete C. Novíssimo Aulete. Dicionário Contemporâneo da Língua Portuguesa. Edição: 1a. Geiger P, editor. Rio de Janeiro: Lexikon; 2011.

46. Yeo $M$, Longhurst $M$. Intimacy in the patient-physician relationship. Committee on Ethics of the College of Family Physicians of Canada. Can Fam Physician Med Fam Can. 1996;42:1505-8.

47. Teal CR, Street RL. Critical elements of culturally competent communication in the medical encounter: A review and model. Soc Sci Med. 2009;68(3):533-43.

48. Thomson R, Yuki M, Talhelm T, Schug J, Kito M, Ayanian AH, et al. Relational mobility predicts social behaviors in 39 countries and is tied to historical farming and threat. Proc Natl Acad Sci. 2018;115(29):7521-6.

49. Hall JA, Coats EJ, LeBeau LS. Nonverbal Behavior and the Vertical Dimension of Social Relations: A Meta-Analysis. Psychol Bull. 2005;131(6):898-924.

50. General Medical Council (Great Britain). Tomorrow's doctors. 2009.

51. Royal College of Physicians of London. Doctors in society: medical professionalism in a changing world; report of a working party. 2005.

52. World Federation for Medical Education. WFME global standards for quality improvement. 2003. 


\section{SUPLEMENTARY MATERIAL}

Escala de Comunicação Interpessoal para Avaliação Observacional das interações médico-paciente (ECI-O).

Por favor, indique o seu nível de concordância com as seguintes afirmações:

(Assinale a opção escolhida na seguinte escala com um $\mathbf{X}$; em caso de erro, preencha por completo o quadrado $\mathbf{\square}$ e assinale com um $\mathbf{X}$ a opção correta).

Discordo fortemente

Concordo fortemente 1 2 3 4 5 6 7

\begin{tabular}{|c|c|c|c|c|c|c|c|c|}
\hline \multicolumn{2}{|r|}{$O(A)$ médico(a)... } & 1 & 2 & 3 & 4 & 5 & 6 & 7 \\
\hline IA1 & estava intensamente envolvido(a) na conversa com o(a) paciente & $\square$ & $\square$ & $\square$ & $\square$ & $\square$ & $\square$ & $\square$ \\
\hline SP10 & fez com que o(a) paciente sentisse que eles(as) eram semelhantes & $\square$ & $\square$ & $\square$ & $\square$ & $\square$ & $\square$ & $\square$ \\
\hline $\mathrm{RC} 15$ & foi sincero(a) & $\square$ & $\square$ & $\square$ & $\square$ & $\square$ & $\square$ & $\square$ \\
\hline $\mathrm{C} 21$ & pareceu muito tenso(a) ao conversar com o(a) paciente ${ }^{b}$ & $\square$ & $\square$ & $\square$ & $\square$ & $\square$ & $\square$ & $\square$ \\
\hline $\mathrm{F} 26$ & interagiu com muita formalidade & $\square$ & $\square$ & $\square$ & $\square$ & $\square$ & $\square$ & $\square$ \\
\hline D29 & tentou persuadir o(a) paciente & $\square$ & $\square$ & $\square$ & $\square$ & 口 & $\square$ & $\square$ \\
\hline IA2 & não quis estabelecer uma relação mais próxima com o(a) paciente ${ }^{b}$ & $\square$ & $\square$ & $\square$ & $\square$ & $\square$ & $\square$ & $\square$ \\
\hline SP11 & tentou direcionar a conversa para aprofundar no assunto & $\square$ & $\square$ & $\square$ & $\square$ & $\square$ & $\square$ & $\square$ \\
\hline $\mathrm{RC} 16$ & estava interessado(a) em conversar com o(a) paciente & $\square$ & $\square$ & $\square$ & $\square$ & $\square$ & $\square$ & $\square$ \\
\hline $\mathrm{C} 22$ & estava calmo(a) diante do(a) paciente & $\square$ & $\square$ & $\square$ & $\square$ & $\square$ & $\square$ & $\square$ \\
\hline $\mathrm{F} 27$ & quis que a discussão fosse casual ${ }^{b}$ & $\square$ & $\square$ & $\square$ & $\square$ & $\square$ & $\square$ & $\square$ \\
\hline IA3 & não estava interessado(a) no(a) paciente ${ }^{b}$ & $\square$ & $\square$ & $\square$ & $\square$ & $\square$ & $\square$ & $\square$ \\
\hline $\mathrm{D} 30$ & não tentou influenciar o(a) paciente ${ }^{b}$ & $\square$ & $\square$ & $\square$ & $\square$ & $\square$ & $\square$ & $\square$ \\
\hline IA4 & achou a conversa empolgante & $\square$ & $\square$ & $\square$ & $\square$ & $\square$ & $\square$ & $\square$ \\
\hline IA5 & transmitiu frieza ao invés de cordialidade ${ }^{b}$ & $\square$ & $\square$ & $\square$ & $\square$ & $\square$ & $\square$ & $\square$ \\
\hline RC17 & quis que o(a) paciente confiasse nele(a) & $\square$ & $\square$ & $\square$ & $\square$ & $\square$ & $\square$ & $\square$ \\
\hline $\mathrm{C} 23$ & pareceu muito tranquilo(a) ao conversar com o(a) paciente & $\square$ & $\square$ & $\square$ & $\square$ & $\square$ & $\square$ & $\square$ \\
\hline D31 & tentou controlar a interação com o paciente & $\square$ & $\square$ & $\square$ & $\square$ & $\square$ & $\square$ & $\square$ \\
\hline IA6 & criou um distanciamento entre ele(a) e o(a) paciente ${ }^{b}$ & $\square$ & $\square$ & $\square$ & $\square$ & $\square$ & $\square$ & $\square$ \\
\hline SP12 & agiu como se ele(a) e o(a) paciente fossem bons(as) amigos(as) & $\square$ & $\square$ & $\square$ & $\square$ & $\square$ & $\square$ & $\square$ \\
\hline RC18 & estava disposto(a) a ouvir o(a) paciente & $\square$ & $\square$ & $\square$ & $\square$ & $\square$ & $\square$ & $\square$ \\
\hline $\mathrm{C} 24$ & pareceu nervoso $(\mathrm{a})^{\mathrm{b}}$ & $\square$ & $\square$ & $\square$ & $\square$ & $\square$ & $\square$ & $\square$ \\
\hline D32 & tentou obter a aprovação do(a) paciente & $\square$ & $\square$ & $\square$ & $\square$ & $\square$ & $\square$ & $\square$ \\
\hline IA7 & agiu como se ele(a) estivesse entediado $(a)^{b}$ & $\square$ & $\square$ & $\square$ & $\square$ & $\square$ & $\square$ & $\square$ \\
\hline SP13 & pareceu querer continuar a comunicação com o(a) paciente & $\square$ & $\square$ & $\square$ & $\square$ & $\square$ & $\square$ & $\square$ \\
\hline RC19 & estava aberto às ideias do(a) paciente & $\square$ & $\square$ & $\square$ & $\square$ & $\square$ & $\square$ & $\square$ \\
\hline $\mathrm{C} 25$ & estava confortável ao interagir com o(a) paciente & $\square$ & $\square$ & $\square$ & $\square$ & $\square$ & $\square$ & $\square$ \\
\hline D33 & não tentou obter a aprovação do(a) paciente ${ }^{b}$ & $\square$ & $\square$ & $\square$ & $\square$ & $\square$ & $\square$ & $\square$ \\
\hline IA8 & estava interessado(a) em conversar com o(a) paciente & $\square$ & $\square$ & $\square$ & $\square$ & $\square$ & $\square$ & $\square$ \\
\hline SP14 & pareceu se importar se o(a) paciente gostou dele(a) ou não & $\square$ & $\square$ & $\square$ & $\square$ & $\square$ & $\square$ & $\square$ \\
\hline $\mathrm{RC20}$ & foi honesto(a) na comunicação com o(a) paciente & $\square$ & $\square$ & $\square$ & $\square$ & $\square$ & $\square$ & $\square$ \\
\hline $\mathrm{F} 28$ & quis que a discussão fosse informal ${ }^{b}$ & $\square$ & $\square$ & $\square$ & $\square$ & $\square$ & $\square$ & $\square$ \\
\hline D34 & teve controle sob a conversa & $\square$ & $\square$ & $\square$ & $\square$ & $\square$ & $\square$ & $\square$ \\
\hline IA9 & demonstrou entusiasmo enquanto conversava com o(a) paciente & $\square$ & ㅁ & ㅁ & ㅁ & $\square$ & $\square$ & ㅁ \\
\hline
\end{tabular}

${ }^{b}$ Reversed items. Burgoon \& Hale 1984, Burgoon \& Hale 1987, Gallagher et al 2001, Gallagher et al 2005. 